
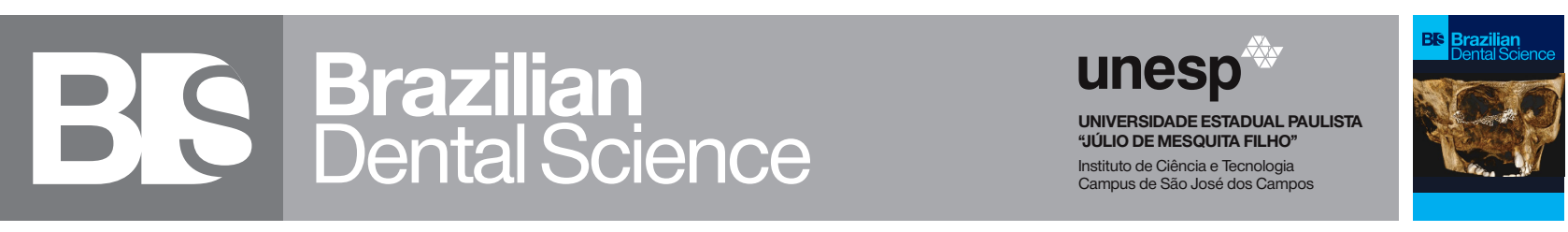

\title{
Clinical Evaluation of Wear Behavior of Human Enamel and Chipping of Veneered Zirconia against Monolithic Zirconia (Randomized Controlled Clinical Trial)
}

Avaliação clínica do comportamento de desgaste do esmalte humano e lascamento da zircônia estratificada contra a zircônia monolítica (ensaio clínico controlado randomizado)

Nouran MAHMOUD ${ }^{1}$, Reham S El BASTY ${ }^{1}$, Hesham A KATAMISH ${ }^{1}$

1 - Faculty of Oral and Dental Medicine - Cairo University - Egypt.

\section{ABSTRACT}

Objective: To evaluate the wear behavior of human enamel and chipping of veneered and monolithic zirconia for posterior full coverage restorations. Material and methods: Thirty-four zirconia full coverage restorations (seventeen in each group) were fabricated. The patients were divided into two groups according to the type of zirconia used; group 1 (comparator group) veneered zirconia crowns and group 2 (intervention group) monolithic zirconia single crowns. All crowns were lab fabricated and polished. For opposing teeth wear measurements 3D non-contact profilometer was used where epoxy resin replicas were constructed for opposing arch immediately after crowns cementation, three, six and twelve months. Restoration chipping was measured using modified United States Public Health Services (USPHS) criteria. Results: All restorations were reported as alpha with no chipping. There was no statistically significant difference between (Group 1) and (Group 2) for wear test. Conclusion: Both monolithic and veneered restorations revealed satisfactory mechanical properties with no chipping after one year of clinical use. Wear of opposing enamel was clinically acceptable for both materials.

\section{KEYWORDS}

Ceramics; Chipping; Monolithic zirconia; Veneered zirconia; Wear.

\section{RESUIMO}

Objetivo: Avaliar o comportamento ao desgaste do esmalte humano e lascamento de zircônia estratificada e monolítica para coroas totais posteriores. Material e métodos: Trinta e quatro coroas totais de zircônia (dezessete em cada grupo) foram fabricadas. Os pacientes foram divididos em dois grupos de acordo com o tipo de zircônia utilizada; grupo 1 (grupo controle) coroas de zircônia estratificada e grupo 2 (grupo de intervenção) coroas de zircônia monolítica. Todas as coroas foram fabricadas e polidas em laboratório. Para medidas de desgaste de dentes opostos, foi utilizado um perfilômetro 3D sem contato, onde réplicas de resina epóxi foram construídas para o arco oposto imediatamente após a cimentação das coroas, três, seis e doze meses após. O lascamento da restauração foi medido usando critérios modificados dos Serviços de Saúde Pública dos Estados Unidos (USPHS). Resultados: Todas as restaurações foram relatadas como alfa sem lascamento. Não houve diferença estatisticamente significativa entre (Grupo 1) e (Grupo 2) para o teste de desgaste. Conclusão: Ambas as coroas monolíticas e estratificadas revelaram propriedades mecânicas satisfatórias sem lascamento após um ano de uso clínico. O desgaste do esmalte oposto foi clinicamente aceitável para ambos os materiais.

\section{PALAVRAS-CHAVE}

Cerâmica; lascamento; Zircônia monolítica; Zircônia estratificada; Desgaste. 


\section{INTRODUCTION}

$\mathrm{M}$ odern dentistry has evolved through many materials and techniques where ceramics had major impact on this development. Zirconia was known for years as the strongest dental material. However, on the list of its drawbacks are wear of the opposing teeth, substantial loss of tooth structure and liability to fracture [1-5]. The relative influencing factors in tooth surface wear opposing to ceramic restorations include the type, microstructure, surface roughness, and the mechanical properties of the material itself. For decades owing to their excellent mechanical properties; multiphase partially stabilized zirconia substructures veneered with feldspathic porcelain has been widely used [6-12]. However, it was reported that the chipping of this veneering may reach up to $40 \%$, accompanied with further wear and fracture of opposing tooth enamel. All this led to the introduction of CAD/CAM fabricated monolithic zirconia as a non-veneering alternative to veneered zirconia eliminating previously stated problems [13-17]. However, there is still concerns about wear of the antagonist which could be attributed to superior hardness of monolithic zirconia surface which is about double that of feldspathic porcelain [18-22]. Also, there's lack of sufficient clinical and laboratory evidence regarding the clinical behavior of this new material especially wear behavior as wear evaluation is a time-consuming and expensive procedures [23-26]. The purpose of this randomized controlled clinical trial was to evaluate chipping and wear of human enamel opposing to full coverage posterior restoration fabricated either from veneered or monolithic zirconia. The null hypothesis was that there would be no difference in the wear or chipping behavior of veneered zirconia compared to monolithic zirconia posterior ceramic crown restoration.

\section{MATERIAL AND METHODS}

This trial was approved by the Ethics Committee of Scientific Research of faculty of Oral and dental medicine, Cairo University in October 2017 (approval number 031017). A written informed consent for all the study procedures and publication of their clinical results and images was obtained from all participants in this trial.
This trial was registered with ClinicalTrial. gov in 09/20/2017 under trial number NCT03295513

Study design: This study was a double blinded randomized controlled clinical trial with an allocation ratio of $1: 1$.

The PICOT for this study were:

Population; Tooth requiring full coverage restoration

Intervention; Polished monolithic zirconia

Comparator; Polished veneered zirconia

Outcome measures:

Primary outcome: Chipping (measured by modified USPHS)

Secondary outcome: Tooth structure loss (wear); (measured by optical profilometry)

Time: one-year clinical follow-up.

Participants:

A total of 34 patients were selected for this study with an age range between 20 to 60 years old. All patients were recruited from the out-patient clinic of the department of fixed prosthodontics, Faculty of Dentistry, Cairo University, Cairo, Egypt. Treatment plan was explained for each patient. They were able and willing to maintain good oral hygiene measures and agreed to sign the informed consent before proceeding to clinical work. Each participant received a full coverage zirconia restoration either veneered " $n=17$ " or monolithic " $n=17$ " in posterior area.

Inclusion criteria:

Adult patients aged 20-60 years old.

Patients with root canal treated posterior teeth requiring full coverage restorations (premolars and molars)

Patients willing to return for follow-up examinations and evaluation.

Patients have opposing sound enamel.

Two non-opposing crowns per patient were set as maximum.

Exclusion criteria:

Patients with poor oral hygiene (papillary 
bleeding index $<35 \%$ or attachment loss).

Patients with no opposing occluding dentition in the area intended for restoration.

Patients have any restoration (direct or indirect) opposing to the crown.

\section{Sample size}

Based on the study of Mundhe et al., 2015 the difference in wear by Optical profilometry between the 2 studied groups was $5 \pm 4.3 \mu \mathrm{m}$ [20]. Using power of $80 \%$ and 5\% significance level, we needed to study 13 in each group. The number was increased to a total sample size of 34 crowns (17 in each group) to allow for losses of around 25\%. Sample size calculation was achieved using PS: Power and Sample Size Calculation Software Version 3.1.2 (Vanderbilt University, Nashville, Tennessee, USA)

Randomization and allocation concealment:

Randomization was done by using computer software (www.randomizer.org) in the center of evidence-based dentistry, Cairo University. The participants were allocated into two groups with 1:1 allocation ratio. Each participant was asked to choose a number from 1 to 34 written on white paper sheet that was folded eight times and saved inside well sealed opaque envelope.

\section{Blinding:}

This trial was a double-blinded randomized clinical trial where participants and outcome assessors were blinded throughout the whole procedures, on the other hand, the operator (the researcher) was not blinded for the purpose of communication with laboratory.

\section{Intervention:}

All clinical procedures were performed by one operator and all laboratory steps were done by one lab technician.

Pre-operative evaluation of teeth, periodontal condition, gingival level, caries index as well as TMJ and muscles of mastication examination was performed before proceeding with any clinical step. Pre-operative photographs for each patient were taken using Canon $6 \mathrm{~d}$, full frame macro lens canon 100L and ring soft box with speed light. All patients received standard hygiene measures (full-mouth scaling and polishing) prior to any clinical step. Diagnostic casts fabricated from alginate impressions (CA 37, Cavex, Haarlem, The Netherlands) were mounted on a semi adjustable articulator using jaw relation records obtained from each patient.

Due to extreme destruction of coronal portion, teeth were restored by glass fiber post (DENTOCLIC, ITENA, France) and compositecore (Dentocore, ITENA, France). Direct fabricated Putty silicon index (Zetaplus,Zhermack, Italy) was taken for provisional restoration construction after tooth restoration. For accurate checking of preparation amount, another putty silicone index was fabricated.

Teeth preparation and final impression:

-For the veneered zirconia crown group, an axial tooth reduction of $1.5 \mathrm{~mm}$, occlusal reduction of $2 \mathrm{~mm}$, and a deep chamfer finish line was done using tapered round diamond bur (850-314-016, Komet, Germany). While for the monolithic zirconia crown, an axial tooth reduction of $1 \mathrm{~mm}$, occlusal reduction of 1 to 1.5 $\mathrm{mm}$, and a deep chamfer finish line was done.

Finishing the preparation was done using fine diamond finishing burs (856EF-314-016, Komet, Germany). Putty silicon index was sectioned to check the amount of reduction for each tooth. Final impression was taken using vinylpolysiloxane addition silicon in plastic stock trays. One step impression technique was performed with putty and light viscosity. light viscosity was applied by using automatic mixing tip and dispensing impression gun which produced complete homogenous mix.

The direct fabricated silicon index was filled with bis-acrylate resin composite material (Structur-2 SC, VOCO, Germany) and placed on the lubricated teeth of the patients intra-orally. After complete setting of temporary material, the silicon index was removed and temporary restoration was removed for proper finishing and polishing, followed by temporary cementation using non-eugenol, acrylic-urethane polymer based temporary cement (RelyX Temp NE, 3MESPE, USA).

Laboratory steps:

Once the dental laboratory received the 
final impression, master casts were poured with a type IV dental stone ((Fuji-Rock-EP, GC-Belgium) according to manufacturer's instruction, with respect to water/powder ratio and mixing time. Vacuum mixing was used to ensure proper mixing and production of void free casts. Dowel pin and die sawing were performed to allow proper designing of the final restoration. An extra oral scanner (DOF "Degree of freedom", South Korea) five axis was used to scan the master cast and a three-dimensional image was obtained for abutment tooth on the computer screen. The final restorations were designed using CAD/CAM software (EXOCADDentalCAD, EXOCAD, Germany), The cement space was set by the software to be 80 microns. Restoration milling was done by 5 -axis milling machine (imes-icore CORiTEC 350i, Germany) the crowns were milled from super translucent katana blanks (Kuraray Noritake) then sintered in sintering furnace (TS-2/M/ZIRKON-120, Germany) according to manufacturer instructions.

Feldspathic veneering "VM9" was used for veneered crowns according to manufacturer instructions with coefficient of thermal expansion slightly lower than the core. A silicone index was taken to standardize the shape and size of veneers with a homogenous veneering thickness of range between $1.00 \mathrm{~mm}$ at margins and $1.5 \mathrm{~mm}$ at occlusal surfaces to avoid any thickening of veneer with anatomical core substructure design with minimum thickness $0.5 \mathrm{~mm}$ and maximum thickness 1.00 $\mathrm{mm}$ according to manufacturer instructions. Polishing for monolithic crowns were done using polishing kit (katana zirconia twist dia, Kuraray Noritak) and polishing Paste (Pearl Surface Z,Kuraray Noritake) recommended by manufacture starting with coarse spiral stone followed by medium then the fine one. While for veneered zirconia polishing was done using polishing kit (OptraFine, Ivoclar Vivadent. Germany) and polishing paste (Optrafine hp" Ivoclar Vivadent. AG, Germany) according to manufacture instructions.

\section{Cementation of zirconia crowns:}

Prior to cementation, the fabricated fullcoverage crowns were checked for marginal fit with a probe and intraoral radiographs were taken to verify. After try in, crowns were cleaned with cleaning paste (Ivoclean, Ivoclar Vivadent AG, Germany) for 20 seconds and rinsed with water followed by application of zirconia primer (Z-Prime Plus, BISCO, USA) to the dried internal surface of the crown for 20 seconds.

After rubber-dam isolation, prophylaxis paste and polishing brush mounted in low speed contra angle were used to clean all teeth surface prior to bonding. Teeth surfaces were dried gently for 5 seconds then self-adhesive luting resin cement (TotalCem, ITENA, France) was applied to the fitting surfaces of the crown using an auto mixing tip. The crown was placed to the tooth in position till complete seating using finger pressure. Excess cement was removed using sharp explorer after 2 seconds of preliminary light polymerization and the crown was then completely light polymerized with an energy density of $480 \mathrm{~mW} / \mathrm{cm}$ for at least 20 seconds from each aspect of the tooth. A waxed dental floss was used inter-dentally for complete removal of excess cement in between crown and adjacent teeth. All patients were instructed to perform brushing and flossing regularly, using non-abrasive fluoridated tooth paste.

\section{Clinical evaluation:}

Restorations evaluation was assessed by three independent assessors for primary and secondary outcomes at baseline, 3, 6 and 12 months.

For chipping evaluation (primary outcome), USPHS criteria were used where; Alpha (Excellent) means the restoration was ideal, Bravo (Acceptable) means the restoration was less than ideal but no modifications required, Charlie refers to restorations with clinically unacceptable defects that could be repaired to a clinically acceptable level, and Delta refers to restoration with an unrepairable problem of clinical relevance. A restoration was regarded successful in absence of any "Charlie" or "Delta" rating, whereas surviving restorations included "Charlie" ratings. With the occurrence of any "Delta" rating, a restoration was judged to be a failure

For wear evaluation (secondary outcome), the maximum wear was quantified as the maximum loss in height. Partial impression was 
taken for opposing arch using vinylpolysiloxane addition silicon in partial stock trays and replicas were manufactured from the epoxy resin at baseline (immediately after cementation), 3, 6and 12-months (Figure 1).

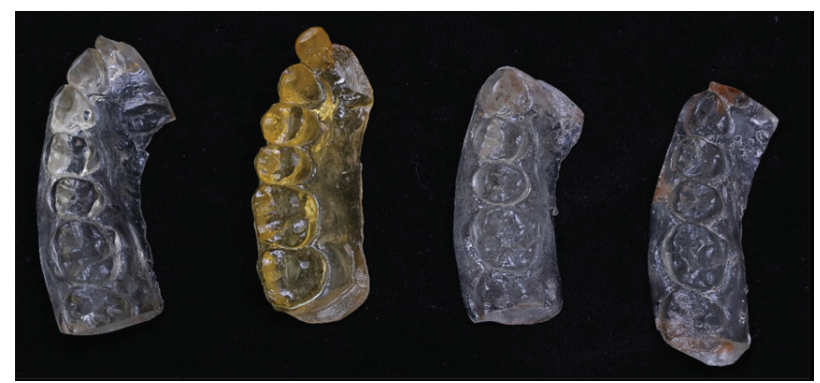

Figure 1- Epoxy Cast (Baseline, 3, 6, 12 months).

The optical method was used for wear evaluation where epoxy resin casts were photographed using USB Digital microscope with a built-in camera connected with an IBM compatible personal computer using a fixed magnification of 120 with a resolution of 1280 $\times 1024$ pixels per image .Digital microscope images were cropped to 350 x 400 pixels using Microsoft office picture manager to standardize area of measurement. The cropped images were analyzed using WSxM software. In this software, all limits, sizes, frames and measured parameters are expressed in pixels. Therefore, system calibration was done to convert the pixels into absolute real-world units. Calibration was made by comparing an object of known size (a ruler in this study) with a scale generated by the software Subsequently, a 3D image of the surface profile of the tooth was created. Five 3D images were collected for each tooth in the central area and in the sides at area of $10 \mu \mathrm{m} \times 10 \mu \mathrm{m}$. These period images were superimposed against one another using tripodization by identifying three points on the occlusal anatomy which are expected to remain stable (i.e. marginal ridges) The cropped images were analyzed using WSxM software to calculate average of heights expressed in $\mu \mathrm{m}$ "Wear measurements".

After proper matching was achieved between different periods of follow up, the maximum wear of teeth at these time periods were compared and recorded. After that, topographic changes were determined by optical profilometer.

\section{Statistical Analysis}

Wear (Loss of height) data were expressed as the mean and standard deviation. After homogeneity of variance and normal distribution of errors had been confirmed, Repeated measure ANOVA was performed to compare between different groups and follow-up periods followed by multiple comparisons with Bonferroni correction. $(\alpha=0.05)$ (IBM SPSS, version 23, Armonk, USA).

\section{RESULTS}

\section{1 - Chipping evaluation:}

The percentages of alpha scores for chipped restoration were $100 \%(n=17)$ for both groups at different recalls with no-record for other scores.

\section{2 - Wear evaluation:}

Repeated measure ANOVA revealed a non-significant effect of different materials and follow-up periods on the wear (Loss of height) ( $p>0.05)$. Furthermore, the interaction between both variables showed a non-significant effect at $\mathrm{p}=0.649$. For all the follow-up periods the loss of height were non-significant after 3,6 and 12 months at $p>0.05$ for both groups. Additionally, Veneered group showed non-significant difference in wear (loss of height) compared to Monolithic groups for all follow-up periods ( $>0.05)$. Descriptive statistics of wear "loss in heights $(\mu \mathrm{m})$ " were summarized in table I. 
Table I - Descriptive statistics of wear results (Mean values \pm SDs) for both groups at different evaluation time

Variables Site Mean \pm SD Min. Max. $\begin{array}{ccc}95 \% \mathrm{Cl} & \text { Statistics } \\ \text { Low High Pvalue }\end{array}$

Baseline $\quad 0.2620 \pm 0.01 \quad 0.24897 \quad 0.29793 \quad 0.2489 \quad 0.2751$

Veneered 3months $0.2693 \pm 0.013 \quad 0.249510 .29055 \quad 0.2548 \quad 0.2837$

Group 6 months $0.2652 \pm 0.0150 .230330 .300650 .24490 .2854$

$0.790 \mathrm{~ns}$

$\begin{array}{lllllll}\text { 1year } \quad 0.2699 \pm 0.021 & 0.22804 & 0.28634 & 0.2254 & 0.3144\end{array}$

$\begin{array}{llllll}\text { Baseline } 0.2682 \pm 0.014 & 0.24427 & 0.28477 & 0.2548 & 0.2817\end{array}$

Monolithic 3months $0.2579 \pm 0.013 \quad 0.24458 \quad 0.28347 \quad 0.2447 \quad 0.2711$

$\begin{array}{lllllllll}\text { group } 6 \text { months } & 0.2614 \pm 0.017 & 0.23290 & 0.29824 & 0.2434 & 0.2794\end{array}$

$0.790 \mathrm{~ns}$

$\begin{array}{llllll}\text { 1year } & 0.2651 \pm 0.02 & 0.21431 & 0.28735 & 0.2289 & 0.3014\end{array}$

\section{3 - Surface topographic changes:}

Topographic changes for enamel surface opposing to veneered and monolithic zirconia were evaluated and different topographic changes were determined by optical profilometer throughout all the follow up periods at baseline (immediately after cementation), 3, 6 and 12 months. Figures (2-5)

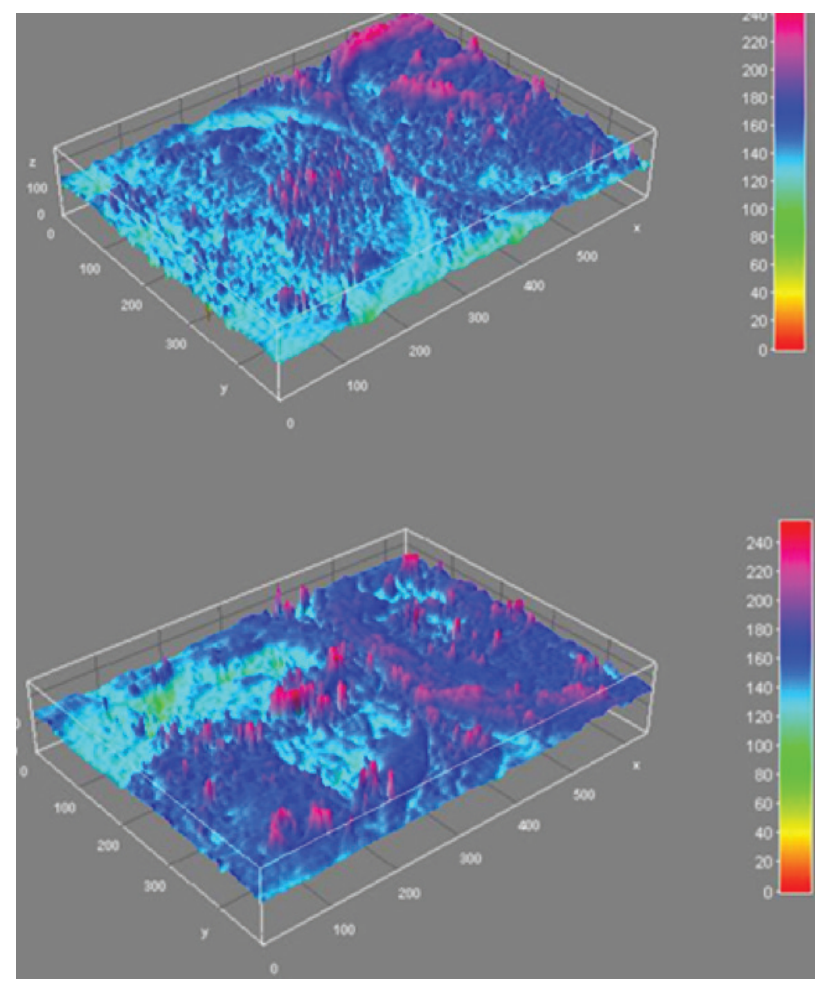

Figure 2 - Surface topographic changes for enamel surface opposing Monolithic zirconia crown "Baseline and 3 months respectively".

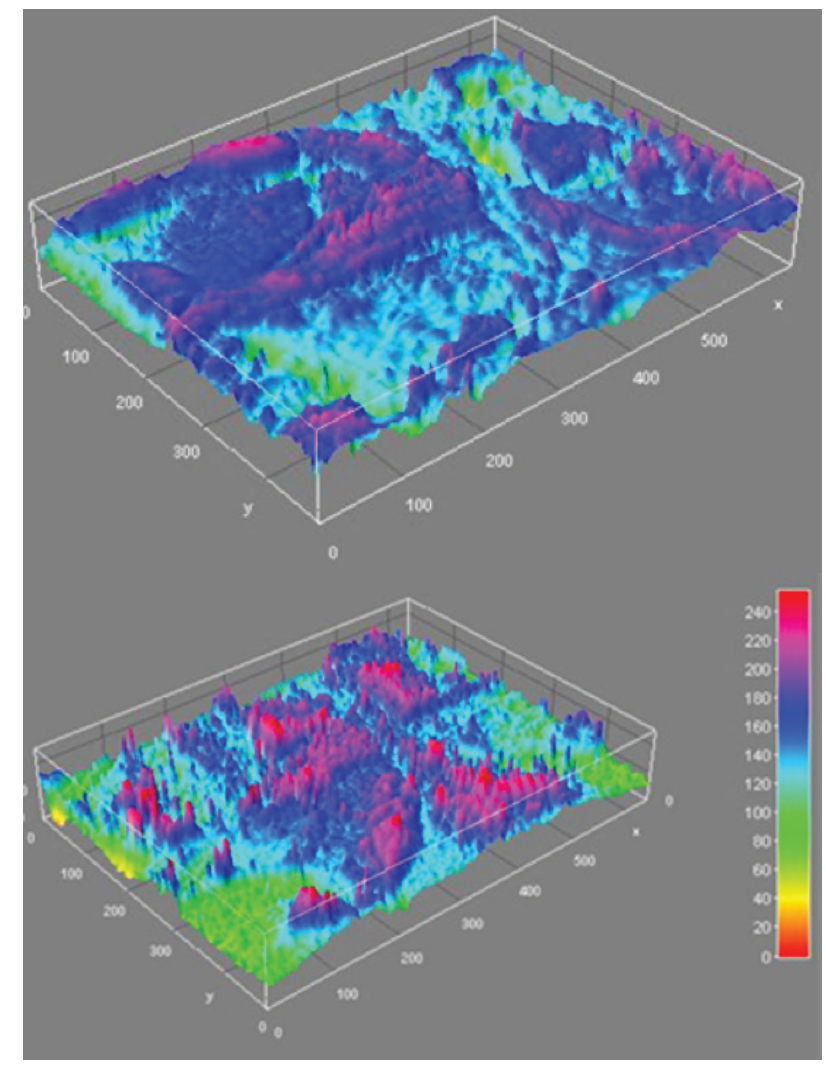

Figure 3 - Surface topographic changes for enamel surface opposing monolithic zirconia crown "6 and 12 months respectively".

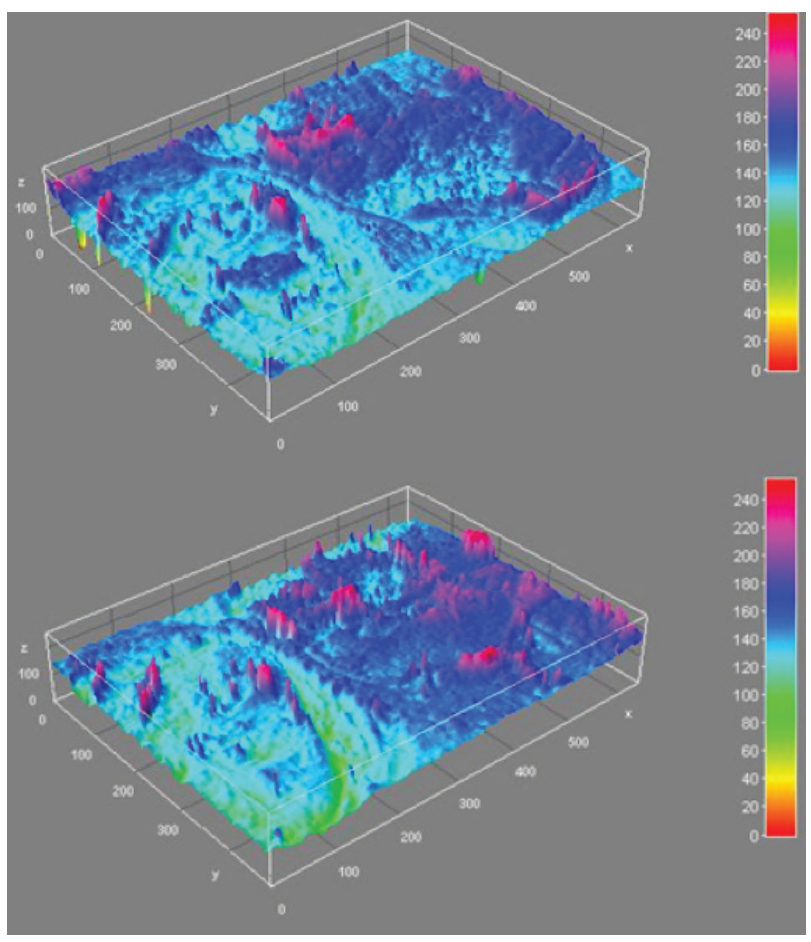

Figure 4 - Surface topographic changes for enamel surface opposing veneered zirconia crown "Baseline and 3 months respectively". 


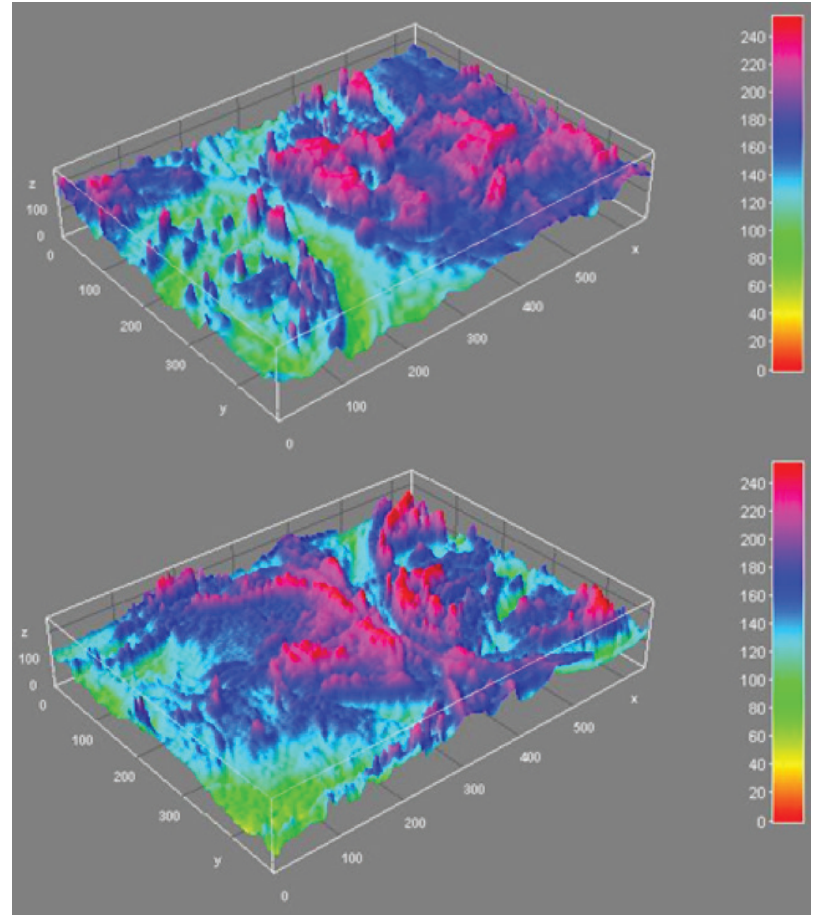

Figure 5 - Surface topographic changes for enamel surface opposing veneered zirconia crown "6 and 12 months respectively".

\section{DISCUSSION}

Chipping of the veneering ceramic is a time-dependent process frequently reported in literature in the form of chipping rate of $10.0 \%$ after 5 years and $21.2 \%$ after 10 years. Other clinical studies reported chipping rate ranging from $0 \%$ to $54 \%$ within the first 3 years. $[27,28]$ As suggested by many clinical and in vitro studies as they tested the performance of full-contour monolithic zirconia, the material was proven to be a valid and more reliable option compared to layered zirconia. According to (Alves.et al ,2019) owing to the elimination of vulnerable porcelain veneering layer; no chipping was reported either clinically or in vitro. Moreover; monolithic zirconia has demonstrated superior mechanical properties and higher fracture resistance in comparison to its counterparts of commercially available ceramics even in minimal thickness and reduced occlusal space requirements. [26]

Many studies have tested wear of hard tooth tissue in variable oral environments and against a large variety of restorative materials. As known for decades, tooth structure wear is a natural process irrespective to the opposing restorative material. And yet many studies have reported delirious effect of some restorative materials especially those of ceramic nature against hard tooth enamel. Tooth surface wear was reported to be a causative factor for too many clinical problems starting with teeth hypersensitivity and damage of occluding surface reaching too severe loss of vertical dimensions and temporomandibular joint dysfunction. [29]

Material overall hardness and surface roughness were frequently reported in literature as major causative factors for opposing tooth surface wear which became a major concern when monolithic zirconia was introduced due to its proven surface hardness. Recent in vitro studies when tested antagonist tooth surface wear against monolithic zirconia in comparison to other ceramic and restorative materials have reported a similar antagonist wear rate as well as an excellent ability of monolithic zirconia restorations to maintain its polished surface after many years of clinical service. On the other hand, clinical observations concluded that feldspathic porcelain veneering of layered zirconia recorded the highest rates of antagonist tooth surface wear compared to other ceramic materials. However, the number of clinical studies that assessed antagonist teeth wear and validate the wear compatibility of the different types of zirconia is limited and it's difficult to rely only on in vitro studies due to their variation regarding the material type, surface finish in addition to the method and type of wear analysis. [30]

Our present study was a randomized double blinded clinical trial where randomization was carried out by using computerized sequence generation (www.randomizer.org) for random allocation of patients to eliminate the risk of selection bias for the included patients. [31]

Participant were clearly informed with the whole treatment procedure and given time to consider the purpose and aims of the study; the likely risks, benefits, and discomforts associated 
with participation. Informed consent was taken from all patients regarding all treatment steps and also the publishing of their clinical results and photographs. [32,33]

As all selected teeth were severely destructed, restoration with glass fiber post and composite core were done first as previously suggested by Aurélio et al, fiber post placement demonstrated to be useful in distributing the stresses and loads applied to the core and prosthetic crown and maximized the clinical longevity of restored teeth. [34]

All crowns fabricated in this study were done by one laboratory technician using one CAD/CAM system. 5-axis milling machine was used for production of all restorations to ensure proper restoration fitting, fewer manual finishing steps and smaller marginal gaps. [35,36]

It was believed that ceramic glazing has the ability to produce smoother, cleansable surfaces and stronger mechanical surface properties than any other ceramic surface treatment. With advances in polishing instruments, it became possible to achieve clinically acceptable surface smoothness, moreover; studies have shown longer lasting smooth and significantly less abrasive surface was more persistent when polishing was used compared to glazed surfaces. by using rotary equipment. [37]

In our study, surface polishing was chosen for all fabricated restorations of both tested groups. [9]

For chipping documentation in this study modified USPHS criteria were used as they provide reliable information regarding the overall long-term success of the restorations.

Replica technique was used in this study to evaluate wear of opposing enamel as it was reported that the best method for measuring wear is by comparing sequential 3D images of the materials of interest.

3D scanning of the entire tooth surface was also reported to be highly accurate, quantitative, applicable to both the clinic and the laboratory and provides storable 3D databases that enable comparison to any another 3D database. Opposing to these findings, Hmaidouch and Weigl, reported that despite cast replicas could quantify the loss of tooth structure, it had some disadvantages as the liability to produce inaccurate replicas resulting from repositioning problems.

Epoxy resin casts were photographed in this study using USB digital microscope because of easier access, affordability and reduced time. [38]

Regarding the wear evaluation, the results showed that no statistically significant difference between veneered and monolithic zirconia with less enamel wear although nonsignificant for monolithic zirconia. This finding may be due to both restorations were polished and it was assumed that polished restorations decrease the enamel wear more than the glazed one. This finding was in agreement with Contreras et al,2018 [39] who reported that polished feldspathic caused less surface roughness for enamel than the glazed. They reported the presence of waved surfaces with numerous irregularities and glaze accumulation in "islands" due to the non-homogeneity of the glaze material and presence gaps in the ceramic surface, while polished surfaces presented only fine scratches resulting from polishing.

Another explanation may be attributed to high fracture toughness of monolithic zirconia (9-10 $\mathrm{MPa}$ ) which was much lower in feldspathic porcelains $(0.73 \mathrm{MPa})$. As the result of application of occlusal loads, microfractures occur in their surface causing porosities and crystalline inclusions sticking out of the surface Moreover, the scraped off particles can act as abrasive and cause three-dimensional wear. Thus, it can be expected that this does not occur in monolithic zirconia due to its high fracture toughness causing less wear in the antagonistic teeth.

Our results were also in agreement with Preis et al, 2012 [40] who reported that polished monolithic zirconia caused less wear for opposing than polished veneered ceramic due 
to their microstructure, complex interactions between glass and crystalline phases and minor mechanical properties porcelains are obviously more prone to microcracking than zirconia.

Also, it was consistent with Ahmadzadeh et al, 2014 who reported that polished monolithic zirconia has a less abrasive effect than polished feldspathic porcelain on opposing natural teeth.

Regarding the chipping evaluation, there was no difference between veneered and monolithic zirconia with no chipping occurred for both groups and all crowns were reported as alpha. This was in agreement with the results of Carames et al, 2019. No chipping in the veneered group could be attributed to production of anatomical supporting frameworks for the veneering porcelain, better control of firing and cooling cycles as well as the use of specific veneering ceramic VM9 with smaller mismatches of coefficients of thermal expansion with substructure. [41]

The results also were in accordance with the results of Konstantinidis et al, 2018 [42] with no chipping for monolithic zirconia after 1 year follow up and all restorations were reported as alpha. Also, it was consistent with Malkondu et al, 2016 [43] who reported that monolithic zirconia ceramics were found to have superior chipping resistance.

Bomicke et al, 2017 [44] reported no statically significant difference between veneered and monolithic zirconia with only one minor chipping for veneered group after 3 years follow up which was also consistent with our results.

The null hypothesis for this study was accepted as no statistically significant difference in the wear or chipping behavior of veneered zirconia compared to monolithic zirconia posterior ceramic restoration was found. However, a longer follow up still needed to determine wear behavior of different polished ceramic restorations.

\section{CONCLUSIONS}

Within limitations of this clinical study, the following conclusions were drawn: Katana super translucent monolithic and veneered full coverage polished revealed satisfactory mechanical properties with no chipping after one year of clinical use.

Wear for the opposing enamel was clinically acceptable for both materials with less enamel wear for monolithic zirconia.

\section{Recommendations:}

Further randomized clinical trials with longer observation time and larger sample size are required to evaluate chipping and wear of veneered zirconia and monolithic zirconia.

\section{REFERENCES}

1. Alves LMM, Contreras LPC, Bueno MG, Campos TMB, Bresciani E, Valera MC, et al. The wear performance of glazed and polished full contour zirconia. Braz Dent J. 2019;30(5):511-8. doi:10.1590/0103-6440201902801

2. ZaroneF,Russo S, Sorrentino R. From porcelain-fused-to-metal to zirconia: clinical and experimental considerations. Dent Mater.2011;27(1):83-96. doi:10.1016/.j.dental.2010.10.024

3. Zkurt-Kayahan Z. Monolithic zirconia: A review of the literature. Biomed Res. 2016;27(4):1427-36.

4. El-Ghany OSA, Sherief AH. Zirconia based ceramics, some clinical and biological aspects. Future Dent J. 2016;2(2):55-64.

5. Partiyan A, Osman E, Rayyan MM, Aboushelib M, Ibrahim A, Jimbo R. Fracture resistance of three-unitzirconia fixed partial denture with modified framework. Odontology.2017;105(1):62-7. doi:10:1007/s10266-016-0242-9

6. Bührer Samra AP,MoraisE, Mazur RF,Vieira SR,Nunes Rached R.CAD/CAM in dentistry-a critical review.J Dent Sci. 2016;31(3).

7. Baldissara P,Wandscher VF,Marchionatti AME, Parisi C,Monaco C, Ciocca L. Translucency of IPS e.max and cubic zirconia monolithic crowns. J Prosthet Dent.2018;120(2):269-75. doi:10.1016/j.prosdent2017.09.007

8. Rashid H, SheikhZ, Misbahuddin S, Kazmi MR, Qureshi S, Uddin MZ Advancements in all-ceramics for dental restorations and their effect on the wear of opposing dentition. Eur J Dent. 2016;10(4):583-8. doi:10.4103/13057456.195170

9. Gou M, Chen H, Kang J, Wang H. Antagonist enamel wear of tooth-supported monolithic zirconia posterior crowns in vivo: A systematic review. J Prosthet Dent. 2019;121(4):598-603. doi:10.1016/.jprosdent2018.06.005

10. Lee SH,Nam SE, Lee SP.Evaluation of the effectiveness of the new tooth wear measurement parameters. AnatCell Biol. 2015;48(4):284-91. doi:10.5115/ acb.2015.48.4.284

11. KontonasakiE, Rigos AE, llia C, Istantsos T. Monolithic zirconia: an update to 
current knowledge. optical properties, wear, and clinical performance. Dent $J$ (Basel). 2019;7(3):90. doi:10.3390/dj7030090

12. Jung YS, Lee JW, Choi YJ, Ahn JS, Shin SW, Huh JB. A study on the in-vitro wear of the natural tooth structure by opposing zirconia or dental porcelain. J Adv Prosthodont. 2010;2(3):111-5. doi:10.4047/jap.2010.2.3.111

13. Kim MJ,OhSH, Kim JH, Ju SW, Seo DG, Jun SH, et al. Wear evaluation of the human enamel opposing different Y-TZP dental ceramics and other porcelains. JDent. 2012;40(11):979-88. doi:10.1016/j.jdent.2012.08.004

14. Sripetchdanond J, Leevailoj C. Wear of human enamel opposing monolithic zirconia, glass ceramic, and composite resin: an in vitro study.J Prosthet Dent 2014;112(5):1141-50. doi:10.1016/.jprosdent.2014.05.006

15. Stober T,Bermejo JL, Rammelsberg P,Schmitter M. Enamel wear caused by monolithic zirconia crowns after 6 months of clinical use. J Oral Rehabil. 2014;41(4):314-22. doi:10.1111/joor.12139

16. Amer R, Kürklü D, KateebE, Seghi RR. Three-body wear potential of dental yttrium-stabilized zirconia ceramic after grinding, polishing, and glazing treatments.JProsthetDent. 2014;112(5):1151-5. doi:10.1016/j. prosdent.2013.12.021

17. Ahmadzadeh A, Hashemi Ashtiani A, Epakchi S, Pormehdi M, Neshati A, Golmohamadi F,etal. Comparison of the effect of feldspathic porcelain and zirconia on natural tooth wear. Islam Dent Assoc Iran. 2014;26(3):170-6.

18. Lawson NC, Janyavula S, Syklawer S, McLarenEA, Burgess JO. Wear of enamel opposing zirconia and lithium disilicate after adjustment, polishing and glazing.J Dent. 2014;42(12):1586-91. doi:10.1016/j.jdent2014.09.008

19. Passos SP, Torrealba Y,Major P,Linke B, Flores-Mir C,Nychka JA. In vitro wear behavior of zirconia opposing enamel: a systematic review published correction appears in J Prosthodont.2014 Dec;23(8):681].JProsthodont. 2014:23(8):593-601. doi:10.1111/jopr.12167

20. Mundhe K, Jain V,Pruthi G, Shah N. Clinical study to evaluate the wear of natural enamel antagonist to zirconia and metal ceramic crowns. JProsthet Dent. 2015;114(3):358-63. doi:10.1016/.jprosdent.2015.03.001

21. Cardelli P,Manobianco FP,Serafini N,Murmura G,Beuer F.Full-Arch, implantsupported monolithic zirconia rehabilitations: pilot clinical evaluation of wear against natural or composite teeth. JProsthodont. 2016;25(8):629-33. doi:10.1111/jopr.12374

22. Stober T, Bermejo JL, Schwindling FS, Schmitter M. Clinical assessment of enamel wear caused by monolithic zirconia crowns. J Oral Rehabil. 2016;43(8):621-9. doi:10.1111/joor.12409

23. Rupawala A, Musani SI, Madanshetty P,Dugal R, Shah UD, Sheth EJ. A study on the wear of enamel caused by monolithic zirconia and the subsequent phase transformation compared to two other ceramic systems. J Indian Prosthodont Soc. 2017;17(1):8-14. doi:10.4103/0972-4052.194940

24. Lohbauer U, Reich S. Antagonist wear of monolithic zirconia crowns after 2 years. Clin Oral Investig. 2017;21(4):1165-72. doi 10.1007/s00784-016-1872-6

25. Esquivel-Upshaw JF,Kim MJ, Hsu SM, Abdulhameed N, Jenkins R, Neal D, et al. Randomized clinical study of wear of enamel antagonists against polished monolithic zirconia crowns. J Dent. 2018;68:19-27.doi:10.1016/j.jdent.2017.10.005

26. Pathan MS, Kheur MG, Patankar AH, Kheur SM. Assessment of antagonist enamel wear and clinical performance of full-contour monolithic zirconia crowns: one-year results of a prospective study.J Prosthodont. 2019;28(1):e411-e416. doi:10.1111/jopr.12960
27. Teichmann M, Wienert AL, Rückbeil M, Weber V,Wolfart S, Edelhoff D. Ten-year survival and chipping rates and clinical quality grading of zirconia-based fixed dental prostheses. Clin Oral Investig. 2018:22(8):2905-15. doi:10.1007/s00784018-2378-1

28. Cantner F,Cacaci C,Mücke T,Randelzhofer P,Hajtó J, Beuer F.Clinical performance of tooth- or implant-supported veneered zirconia single crowns: 42-month results. Clin Oral Investig. 2019;23(12):4301-9. doi:10.1007/s00784019-02878-0

29. Hmaidouch R, Weigl P. Tooth wear against ceramic crowns in posterior region: a systematic literature review. Int J Oral Sci. 2013;5(4):183-90. doi:10.1038/ ijos.2013.73

30. Ashtiani AH, Azizian M, Rohani A. Comparison the degree of enamel wear behavior opposed to Polymer-infiltrated ceramic and feldspathic porcelain DentRes J (Isfahan). 2019;16(2):71-5.

31. Dettori J. The random allocation process: two things you need to know. Evid Based Spine Care J. 2010;1(3):7-9. doi:10.1055/s-0030-1267062

32. Dowrick $A S$, Bhandari M. Ethical issues in the design of randomized trials: to sham or not to sham. JBone Joint Surg Am. 2012;94 Suppl 1:7-10. doi:10.2106/ JBJS.L.00298

33. Mladenović D, Mladenović L, Mladenović S. Importance of digital dental photography in the practice of dentistry. Scientific Journal of the Faculty of Medicine in Niš 2010;27(2):75-9.

34. Aurélio IL, Fraga S, Rippe MP, Valandro LF. Are posts necessary for the restoration of root filled teeth with limited tissue loss? A structured review of laboratory and clinical studies. Int Endod J. 2016;49(9):827-35. doi:10.1111/ iej.12538

35. Aladağ A, OğuzD, Çömlekoğlu ME, Akan E In vivo wear determination of novel CAD/CAM ceramic crowns by using 3D alignment. J Adv Prosthodont. 2019;11(2):120-7. doi:10.4047/jap.2019.11.2.120

36. Kirsch C,Ender A, Attin T,Mehl A. Trueness of four different milling procedures used in dental CAD/CAM systems. Clin Oral Investig. 2017;21(2):551-8. doi:101007/s00784-016-1916-y

37. Azeez SM, Salih SA. Qualitative and quantitative evaluations of topography for CAD/CAMall ceramic zirconia after different surface treatments. Erbil DentJ. 2019;2(1):164-72. doi:https://doi.org/10.15218/edj.2019.06

38. Horcas I,Fernández R, Gómez-Rodríguez JM, Colchero J,Gómez-Herrero J, Baro AM. WSXM: a software for scanning probe microscopy and a tool for nanotechnology. Rev Sci Instrum. 2007;78(1):013705. doi:10.1063/1.2432410

39. Contreras LP,Dal Piva AM, Ribeiro FC, Anami LC, Camargo SE, Jorge A0, et al. Effects of manufacturing and finishing techniques of feldspathic ceramics on surface topography, biofilm formation, and cell viability for human gingival fibroblasts. Oper Dent. 2018;43(6):593-601. doi:10.2341/17-126-L

40. Preis V, Behr M, Handel G, Schneider-Feyrer S, Hahnel S, Rosentritt M. Wear performance of dental ceramics after grinding and polishing treatments. $J$ Mech Behav Biomed Mater.2012;10:13-22. doi:10.1016/j.jmbbm.2012.03.002

41. Caramês J, Marques D, Malta Barbosa J, Moreira A, Crispim P,Chen A. Full-arch implant-supported rehabilitations: a prospective study comparing porcelainveneered zirconia frameworks to monolithic zirconia. Clin Oral Implants Res. 2019;30(1):68-78. doi:10.1111/clr.13393 
42. Konstantinidis I TrikkaD, Gasparatos S, Mitsias ME Clinical outcomes of monolithic zirconia crowns with cad/cam technology. a1-year follow-up prospective clinical study of 65 patients. Int J Environ Res Public Health. 2018;15(11):2523. doi:10.3390/ijerph15112523
43. Malkondu Ö, Tinastepe N, AkanE, KazazoğluE. An overview of monolithic zirconia in dentistry. Biotechnol biotechnol equipment. 2016;30(4):644-52.

44. Bömicke W, Rammelsberg P,Stober T,Schmitter M. Short-term prospective clinical evaluation of monolithic and partially veneered zirconia single crowns. $J$ Esthet Restor Dent. 2017;29(1):22-30. doi:10.1111/jerd.12270

\section{Nouran Mahmoud Ibrahim Metwally}

\section{(Corresponding address)}

Faculty of Oral and Dental Medicine - Cairo University - Egypt. 